\title{
Invited review: Sustainable forage and grain crop production for the US dairy industry
}

\author{
N. P. Martin, ${ }^{*}$ M. P. Russelle,† J. M. Powell, ${ }^{*}$ C. J. Sniffen, $\ddagger$ S. I. Smith,§ J. M. Tricarico,\# and R. J. Grant II \\ *US Dairy Forage Research Center, USDA-Agricultural Research Service, Madison, WI 53706 \\ †Department of Soil, Water, and Climate, University of Minnesota, Saint Paul, 55108 \\ łFencrest LLC, Holderness, NH 03245 \\ §USDA-National Institute of Food and Agriculture, Washington, DC 20024 \\ \#Innovation Center for US Dairy, Rosemont, IL 60018 \\ IIWilliam H. Miner Agricultural Research Institute, Chazy, NY 12921
}

\section{ABSTRACT}

A resilient US dairy industry will be underpinned by forage and crop production systems that are economically, environmentally, and socially sustainable. Land use for production of perennial and annual forages and grains for dairy cattle must evolve in response to multiple food security and environmental sustainability issues. These include increasing global populations; higher incomes and demand for dairy and other animal products; climate change with associated temperature and moisture changes; necessary reductions in carbon and water footprints; maintenance of soil quality and soil nutrient concerns; and competition for land. Likewise, maintaining producer profitability and utilizing practices accepted by consumers and society generally must also be considered. Predicted changes in climate and water availability will likely challenge current feed and dairy production systems and their national spatial distribution, particularly the western migration of dairy production in the late 20th century. To maintain and stabilize profitability while reducing carbon footprint, particularly reductions in methane emission and enhancements in soil carbon sequestration, dairy production will need to capitalize on genetic and management innovations that enhance forage and grain production and nutritive value. Improved regional and on-farm integration of feed production and manure utilization is needed to reduce environmental nitrogen and phosphorus losses and mitigate greenhouse gas emissions. Resilient and flexible feed production strategies are needed to address each of these challenges and opportunities to ensure profitable feeding of dairy cattle and a sustainable dairy industry.

Key words: nutrient, greenhouse gas, manure, stocking rate, environment

Received April 26, 2017.

Accepted August 17, 2017.

${ }^{1}$ Corresponding author: grant@whminer.com

\section{INTRODUCTION}

Sustainable food security is the ultimate goal of agricultural production systems. The global population is predicted to grow substantially through 2050, necessitating enormous increases in food production as well as reductions in food waste (Fedoroff, 2015). We expect that the US dairy industry will increase milk production - specifically production of milk protein and fat - in response to increasing global demands for dairy products. To reduce competition for land, increased milk production will require more productive and environmentally beneficial forage and grain cropping systems.

Over the past 2 decades, rapid expansion of US milk production in western states shifted production away from the Midwest and Northeast, and most milk now comes from larger dairy enterprises (MacDonald et al., 2016). Stocking rates have increased on many dairy farms, requiring them to obtain feedstuffs, primarily grain and by-products, from outside sources. These farms do not own or have access to the required land base to allow for sustainable recycling of manure nutrients. Phosphorus accumulation in soils due to repeated manure applications, especially manure from high Pcontaining diets (Powell et al., 2002) and fertilizers, has increased P runoff into surface waters (Lanyon, 1992; Ebeling et al., 2002; Sharpley and Sims, 2005). Elevated $\mathrm{P}$ concentration in water promotes weed and algae growth, which eventually depletes dissolved oxygen levels, leading to fish kills, odors, and a general decline in ecological status (Sims and Sharpley, 2005). Nitrogen losses from some dairy farms have been linked with groundwater aquifer contamination (Harter et al., 2013) and surface water contamination (Vadas et al., 2015). Dairy farms in the Upper Midwest appear to contribute to hypoxia in the Gulf of Mexico (Blesh and Drinkwater, 2013; Blesh and Wolf, 2014).

Risk of nitrate loss from fields is exacerbated by annual cropping, which leaves gaps in water and nitrate 
uptake during the year (Randall et al., 1997); by excessive or inefficient irrigation, which is partly driven by poor water use efficiency by primary crops and forages (Carter and Sheaffer, 1983; Dietzel et al., 2016); by excessive or poorly managed manure application, which is magnified by inadequate access to cropland (Powell et al., 2002; Saam et al., 2005); by simple, but rigid crop rotations (Randall et al., 1997); and by a lack of strategic ration formulation and the use of improved crop and forage components that improve manure composition (Somda et al., 1995; Powell et al., 2009). Strategic ration formulation has been impeded by lack of crucial forage analytical techniques (Van Middelaar et al., 2014; Van Amburgh et al., 2015), which will be needed increasingly as new crop traits are introduced (Lei et al., 2017).

Livestock and dairy are also especially vulnerable to water shortages and climate change. Animal agriculture accounts for $27 \%$ of the global water footprint of human activity and $98 \%$ of that water is used for animal feed production (Hoekstra, 2012). Matlock et al. (2013) indicated that the major challenge for US dairy producers is irrigation water to grow feed rather than on-farm water use (i.e., drinking, cooling, and washing).

Through water limitations and heat stress, long-term changes in climate will challenge cropping systems aimed at providing high-quality forages and other feeds to maintain healthy, high-producing dairy cows. The United States is likely to warm substantially over the next $40 \mathrm{yr}$, with an increase of 1 to $2^{\circ} \mathrm{C}$ in average annual air temperature predicted throughout the country. Some regions, such as the interior of the United States, may experience increases of 2 to $3^{\circ} \mathrm{C}$ (Walthall et al., 2012). Current crops suffer major yield losses under the multiple stressors that climate change is expected to present (Hatfield et al., 2017).

Crops and forages play crucial roles as feed for the herd, as determinants of manure composition, and as receivers of manure. Therefore, sustainable feed production, rations, and nutrient management will provide the foundation on which a resilient dairy industry can be developed. Our specific objectives in this analysis were to (1) provide historical context to the present state of the US dairy industry and associated land use and cropping that support the industry; (2) critically evaluate the strengths and weaknesses of the present forage and grain cropping systems used by the US dairy industry; (3) identify potential challenges and opportunities facing US dairy forage and grain cropping systems through mid-century; and (4) advance possible approaches for the US dairy industry to capitalize on these opportunities and mitigate risks.

\section{INTENSIFICATION OF THE DAIRY INDUSTRY}

Advances in animal genetics, nutrition, and herd management resulted in a 4-fold improvement in milk yield between 1944 and 2007 (Capper et al., 2009). Consequently, the US dairy industry now produces $59 \%$ more milk with $64 \%$ fewer cows that consume $77 \%$ less feed per unit of milk produced. Much of this improvement in productivity has occurred in the past 3 decades, during which the US dairy industry has undergone substantial structural change.

Two decades ago, most milk came from farms with fewer than 150 cows, on which family members handled milking, herd management, and crop production for feed (MacDonald et al., 2016). Today, most milk comes from farms with more than 900 cows (MacDonald et al., 2016). Whereas most of these farms are owned and operated by a family, much of the labor is provided by hired workers and many farms purchase most or all of their feed. Over the past $20 \mathrm{yr}$, dairy farm numbers declined by nearly $60 \%$ (MacDonald and Newton, 2014). This decline is almost entirely a consequence of small dairy farms exiting the industry. The 135,000 farms that had fewer than 100 cows in 1998 were reduced to approximately 50,000 by 2012 . In contrast, during the same period (1998-2012), the number of dairy farms with at least 1,000 cows more than tripled to 1,807 (MacDonald et al., 2016).

The net effect of these structural changes has been to concentrate milk production on fewer farms with less directly owned land base per cow. For example, herds of 200 to 699 cows average approximately 1 cow per hectare, whereas herds larger than 999 cows average 2.2 cows per hectare (MacDonald et al., 2007). The distribution of animal density among farms varies by state, with $<1$ lactating cow per hectare on over $85 \%$ of Wisconsin dairy farms but on less than $5 \%$ of California dairies (Figure 1; Powell et al., 2010a). New, larger facilities generally have avoided investment in land (Isik, 2004). For example, the densest $1 \%$ of California dairy farms had about 955 cows per hectare in 2002 (Powell et al., 2010a). Increasing density of animal populations on many dairy farms has greatly increased reliance on purchased feed and directly affects manure and nutrient recycling and environmental losses, and we discuss this fundamental challenge in depth in a later section. Negative perceptions of larger farm size by society continue (Boogaard et al., 2010), and whether large farms (in terms of animal numbers) are socially sustainable in the long run has been, and will no doubt continue to be, a major point of discussion [see review by Robbins et al. (2016) for further discussion]. 


\section{CHANGING LAND USE PATTERNS}

Intensification of the US dairy industry has affected land use. Historically, dairy farms used pasture and crops produced on the farm's land base to feed the herd, and purchased only minimal protein, energy, minerals, and vitamins needed to meet cattle nutrient requirements. Over the past few decades, crop and dairy operations have tended to separate to take advantage of cost efficiencies, excellent transportation infrastructure, and regulatory programs and policies (Lanyon, 2005). Despite fairly constant dairy cattle numbers in the United States (Figure 2), land use for crop production on US dairy farms declined by $65 \%$ between 1974 and 2012, with the majority of this decline arising from reductions in harvested cropland $(42 \%)$, followed by pasture (19\%; Figure 2). At the same time, cropland has become concentrated in the northern plains and Corn Belt regions of the United States (Nickerson et al., 2011).

Dairy farms primarily grow corn (for silage and grain), but also alfalfa, soybeans, oats, wheat, barley, and sorghum, depending on the region (USDA-NASS, 1977, 1981, 1984, 1989, 1994, 1999, 2004, 2009, 2014). However, with the exception of soybeans, the number of hectares devoted to grain production has declined dramatically since 1974 , primarily due to increases in crop yield that have maintained production per farm.

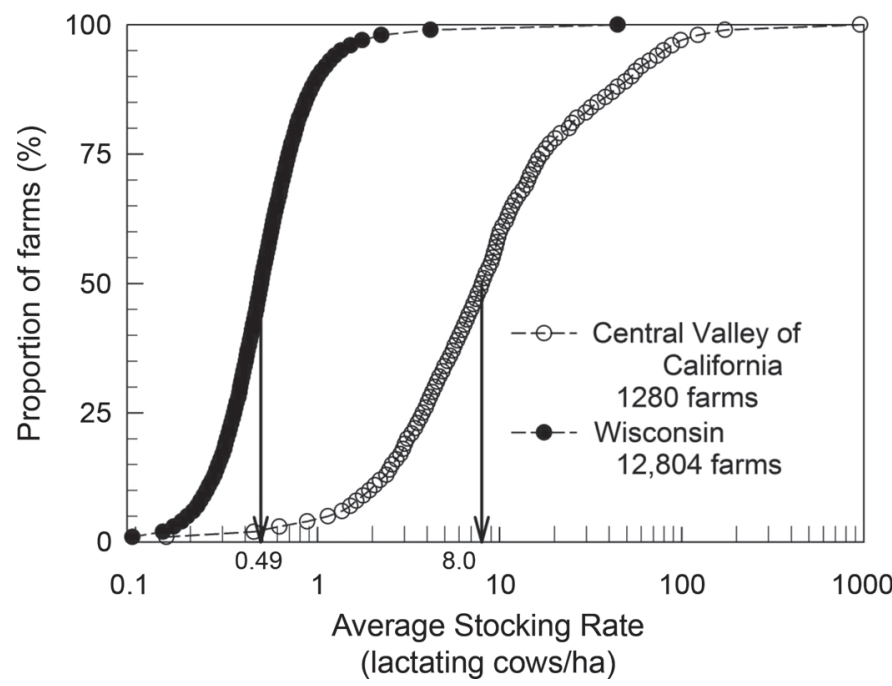

Figure 1. Cumulative frequency of lactating cows per unit land area managed by the dairy operator for 2 important milk-producing regions of the United States in 2002. The smaller amount of land managed by the dairy operator per animal is evident in the central valley of California in comparison to Wisconsin [adapted from Powell et al. (2010a), with permission from Livestock in a Changing Landscape: Vol. II, ed. Gerber, P., C. de Haan, J. Dijkman, H. A., Mooney, and S. Tarawali, ed. Copyright 2010 Scientific Committee on Problems of the Environment (SCOPE). Reproduced by permission of Island Press, Washington, DC].
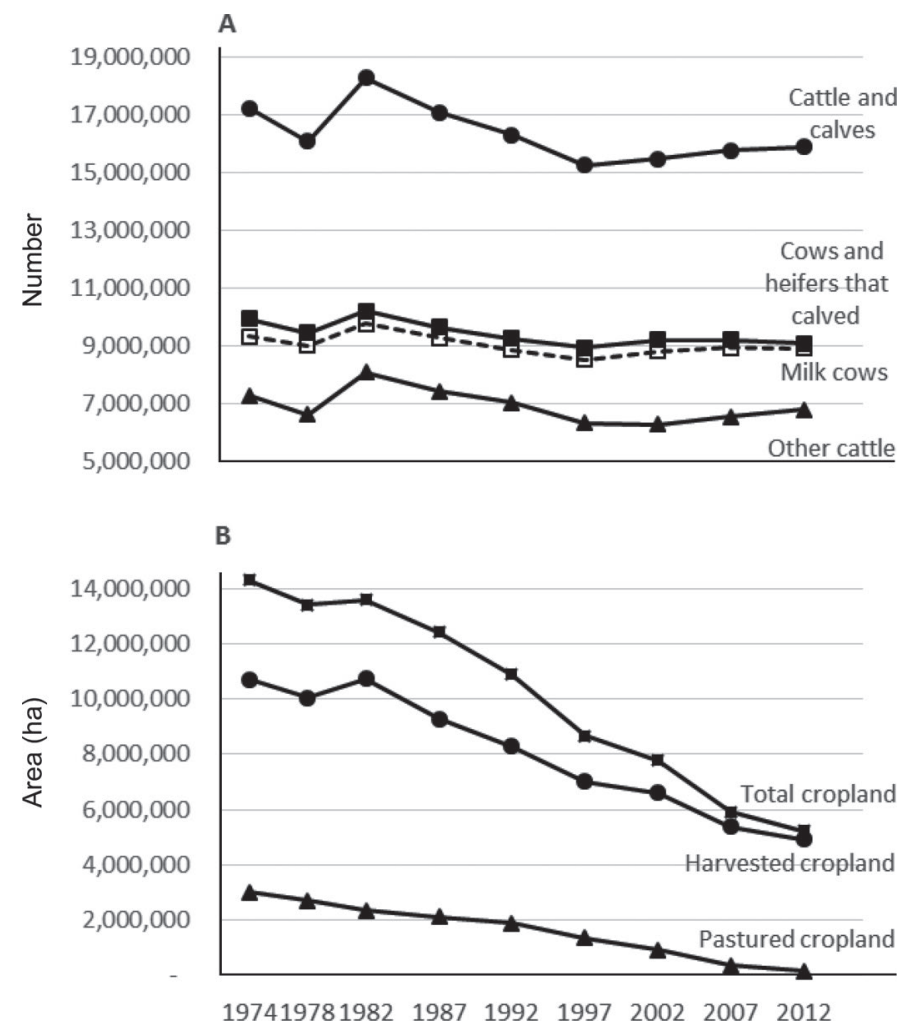

Figure 2. Changes over time (1974 to 2012) in the number of dairy cattle (A) and cropland area in hectares (B) in US dairy farms according to census of agriculture data from USDA-NASS (1977, 1981, 1984, 1989, 1994, 1999, 2004, 2009, 2014).

The number of hectares harvested for hay, hay crop silage, grass silage, and green chop peaked in 1982 and declined afterward. In contrast, hectares harvested for corn silage remained largely unchanged between 1982 and 2012 (Figure 3). Importantly, the production of corn silage increased by $33 \%$, whereas alfalfa hay production decreased by $75 \%$, and production of hay, hay crop silage, grass silage, and green-chop decreased by $32 \%$ (Figure 3 ). The greater decline in alfalfa hay is likely explained by the expansion of alfalfa acres harvested as hay crop silage rather than dry hay, as fewer farms reported use of hay compared with silage (data not shown).

The increased production of corn for silage mirrors the growing reliance on corn silage as a primary forage source for cattle (Higginbotham and Karlin, 2008; Robinson, 2008). Over a recent 30-yr period (1982-2012), cropland devoted to corn silage increased $75 \%$ on dairy farms, from 18 to $31 \%$ of cropped acres. This trend has allowed dairy producers to increase herd size and stocking rates; approximately $27 \%$ more cows per unit land area can be fed when corn silage replaces alfalfa silage in the cropping pattern (Powell et al., 2016). Drivers favoring corn silage compared with alfalfa include (1) 
higher DM yield, especially in the warmer environments where dairy has been expanding; (2) higher energy content; (3) more uniform quality; and (4) one, rather than multiple, required harvests (Klemme, 1998; Rankin, 2014). The 2- to 3-fold yield gap between average and top-tier alfalfa producers (Russelle, 2013) indicates that the first of these drivers may be exaggerated by poor alfalfa management on many farms.

\section{ENVIRONMENTAL IMPLICATIONS OF FEEDS USED IN STANDARD DAIRY CATTLE DIETS}

Thoma et al. (2013b) computed a US national average dairy ration from 350 farm survey results. This national average ration included regionally weighted rations for calves, open heifers, bred heifers, first-calf heifers, springers (i.e., dairy cows due to deliver calves within a few weeks), lactating cows, and dry cows, and accounted for forage grazed during the year. Although there is no true US average ration that is fed, the computed national US average dairy ration is made up of a set of 33 ingredients (Figure 4).Ten ingredients are forages that account for $53 \%$ of dietary DM, and 23 are concentrates that account for the remainder. Nearly one-fifth of these ingredients are by-products, including 14 from the food, fuel, and fiber industries (Tricarico, 2016).

The growing, storage, and feeding of the national dairy diet components and recycling the manure derived from them affect environmental nutrient losses (Figure 5). Much of the urinary $\mathrm{N}$ contained in manure can be lost as $\mathrm{NH}_{3}$ from dairy barns, manure storage, and after land application. Portions of fertilizer $\mathrm{N}$ and land-applied manure $\mathrm{N}$ are lost as $\mathrm{NO}_{3}{ }^{-}$to groundwater. Phosphorus runoff can impair surface waters, particularly where manure is land-applied without tillage. Nitrous oxide, the most potent agricultural greenhouse gas (GHG), and $\mathrm{CH}_{4}$, the second most potent GHG from agriculture, are emitted directly by cows and from stored and applied manure.

Nearly three-fourths of cradle-to-grave (i.e., effect created from the beginning of life cycle to its end or disposal) GHG emissions from US fluid milk occurs before milk leaves the farm (Thoma et al., 2013a). Greenhouse gas emissions incurred during crop production (i.e., direct field emissions and emissions embedded in fuel, electricity, fertilizers, and pesticides) represent $19 \%$ of the cradle-to-grave and $26 \%$ of the cradle-to-farm gate (i.e., effect created from the beginning of life cycle to milk leaving the farm) GHG emissions from US dairy farms (Thoma et al., 2013a). Enteric $\mathrm{CH}_{4}$ and both $\mathrm{CH}_{4}$ and $\mathrm{N}_{2} \mathrm{O}$ from manure storage, processing, and land application are the other major sources of GHG emissions on the dairy farm (Veltman et al., 2017). Growing the primary forages used in dairy rations, alfalfa and corn silage, results in similar (170 to $200 \mathrm{~g}$ of $\mathrm{CO}_{2}$ equivalents per kilogram of DM) GHG emissions (Adom et al., 2012). In contrast, GHG emissions from production and processing of purchased feed ingredients (390 to $910 \mathrm{~g}$ of $\mathrm{CO}_{2}$ per kilogram of DM) are 2 to 5 fold larger than production of forage crops.

Feeding by-products may result in excessive dietary nutrients, such as $\mathrm{P}$, requiring nutrient management plans to be adjusted for higher $\mathrm{P}$ excretion in manure (Schmit et al., 2009). However, when diets are properly formulated to contain by-products from human food and fiber production, the environmental impact of milk production will be reduced through decreases in GHG emissions and greater overall nutrient use efficiency (Russomanno et al., 2012).

\section{STOCKING RATES AFFECT NUTRIENT USE AND ENVIRONMENTAL PERFORMANCE}

Fundamental to sustainable dairy production are land stocking rates that provide acceptable farm profit while optimizing nutrient use efficiency and minimizing negative effects on the environment. The terms stocking rate and carrying capacity usually are applied to
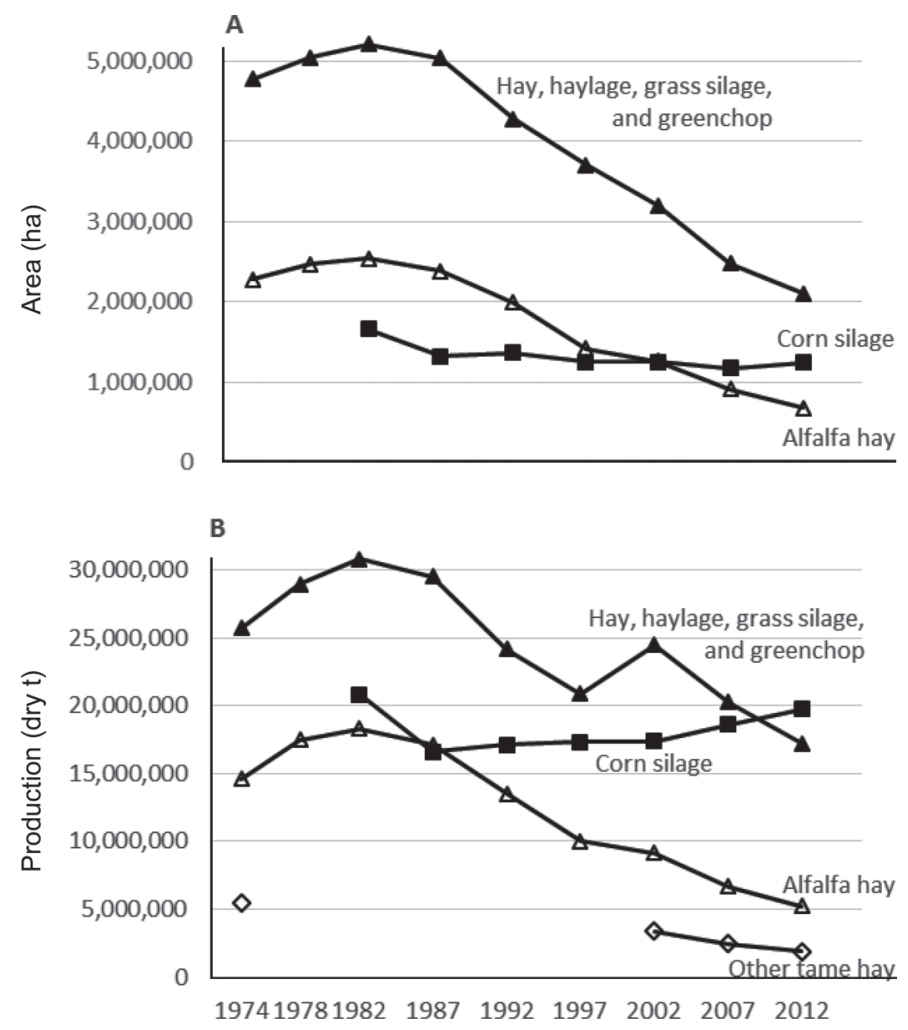

Figure 3. Changes over time (1974 to 2012) in cropland area in hectares (A) and production in dry metric tons (B) of forage crops in US dairy farms according to census of agriculture data from USDANASS $(1977,1981,1984,1989,1994,1999,2004,2009,2014)$. 
INVITED REVIEW: US FORAGE AND CROP PRODUCTION

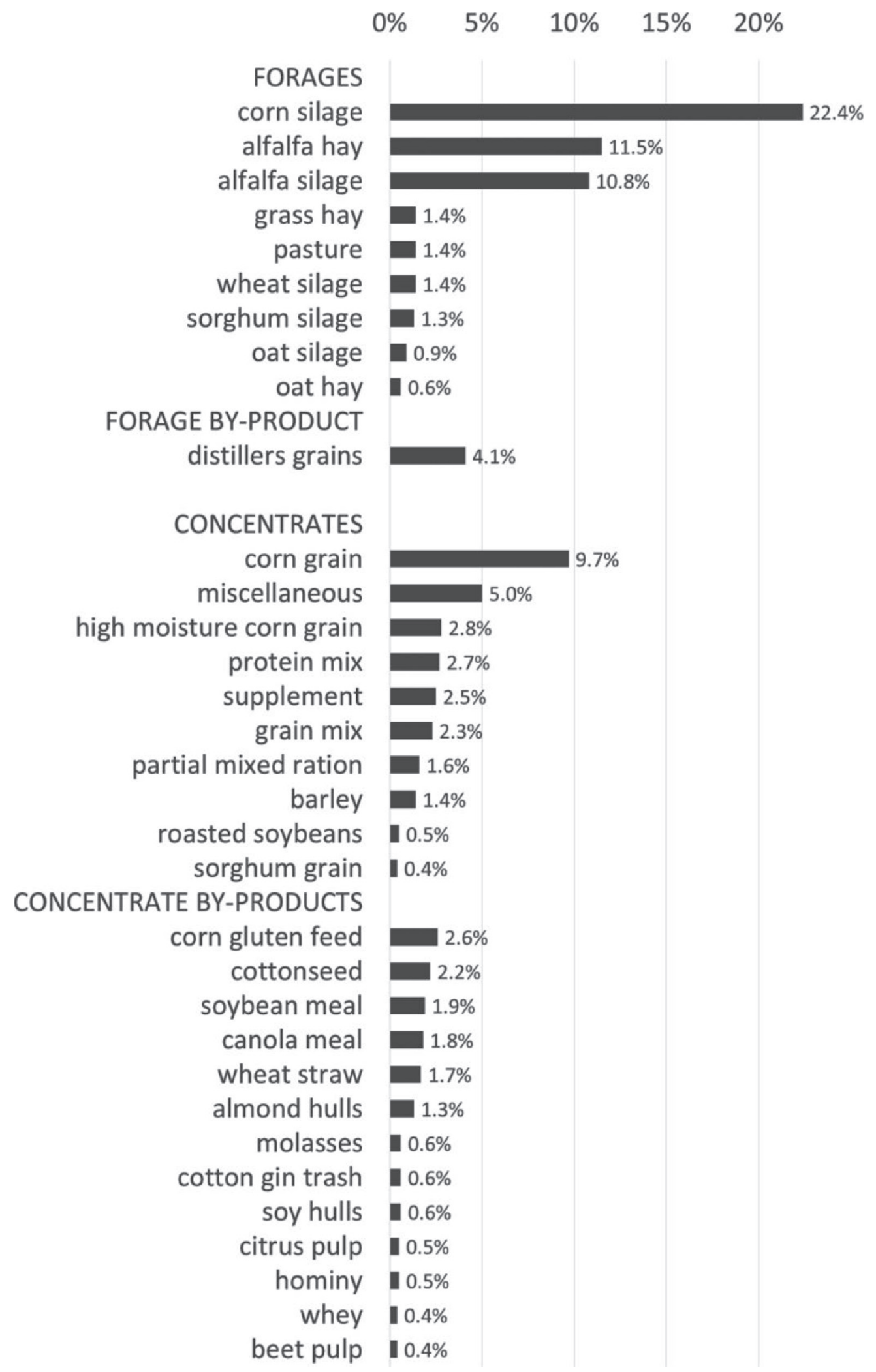

Figure 4. Composition of a national average dairy ration (on a DM basis) computed from 350 farm survey results conducted for a life cycle assessment of greenhouse gas emissions from production of fluid milk in the United States (Thoma et al., 2013b). The national average ration includes regionally weighted rations for calves, open heifers, bred heifers, first calf heifers, springers, lactating cows, and dry cows, and accounts for forage grazed during the year. 
grazing-based dairy farms to assess relationships among land, pasture production, and animal feed requirements (Redfearn and Bidwell, 2007). But the concept of stocking rate should also be applied to confinement-based dairy farms to assess relationships among land, forage and grain production, feed requirements, and the ability of the land base to recycle the nutrients contained in manure.

In Wisconsin, dairy farms having fewer than 1.4 animal unit (AU; $454 \mathrm{~kg}$ of live weight) per hectare are able to produce sufficient forage and grain to meet herd demands; they also have adequate cropland to recycle the $\mathrm{N}$ and $\mathrm{P}$ contained in manure (Powell et al., 2002; Saam et al., 2005), as long as dietary $\mathrm{P}$ is not excessive. In New York State, dairy farms that have 2.4 AU/ ha and feed adequate amounts of dietary $\mathrm{P}(0.40 \%$ of dietary DM) are able to effectively recycle the manure $\mathrm{P}$, but at higher dietary $\mathrm{P}$ levels the stocking rate for effective manure $\mathrm{P}$ recycling declines to $1.4 \mathrm{AU} / \mathrm{ha}$ (Cela et al., 2014). Part of the discrepancy between the assessments in Wisconsin and New York State may be due to soil texture; as Saam et al. (2005) observed, finetextured soils are less likely to be in a condition for manure application in spring and fall, requiring more land area per animal unit for reliable manure application. Dry-lot dairy operations, such as those located in the central valley of California, have the highest stocking rates and, therefore, the greatest challenges in effective, overall nutrient management unless alternative uses are found for manure, such as off-farm export (Powell et al., 2010a).

Whole-farm $\mathrm{N}$ use efficiency, which is the fraction of all $\mathrm{N}$ inputs (fertilizer, biologically-fixed, manure) divided by total $\mathrm{N}$ removed in crops, pasture, milk, and meat, is reduced as alfalfa is replaced by corn silage (Powell et al., 2010b, 2017). Reductions in N use efficiency are accompanied by increases in $\mathrm{N}$ losses via $\mathrm{NH}_{3}, \mathrm{~N}_{2} \mathrm{O}$, and $\mathrm{NO}_{3}{ }^{-}$(Powell and Rotz, 2015). However, if the goal is to reduce negative environmental and climate change effects, it may be more important to focus on the amount of $\mathrm{N}$ surplus on a farm $(\mathrm{kg}$ of N/ha per year) as the benchmark (de Klein et al., 2017). In the future, appropriate farm stocking rates and associated dairy rations that leverage efficient production of forages and home-grown feeds will be more sustainable than dairy farm systems that rely heavily on imported feed, and, as a consequence, produce manure that exceeds nutrient recycling capacities resulting in environmental contamination (Powell et al., 2010a,b; Cela et al., 2014).

\section{NUTRIENT CYCLING AND ENVIRONMENTAL OUTCOMES OF MILK PRODUCTION}

Increasing evidence has shown that fertilizer and manure $\mathrm{N}$ contribute to water and air quality impair-

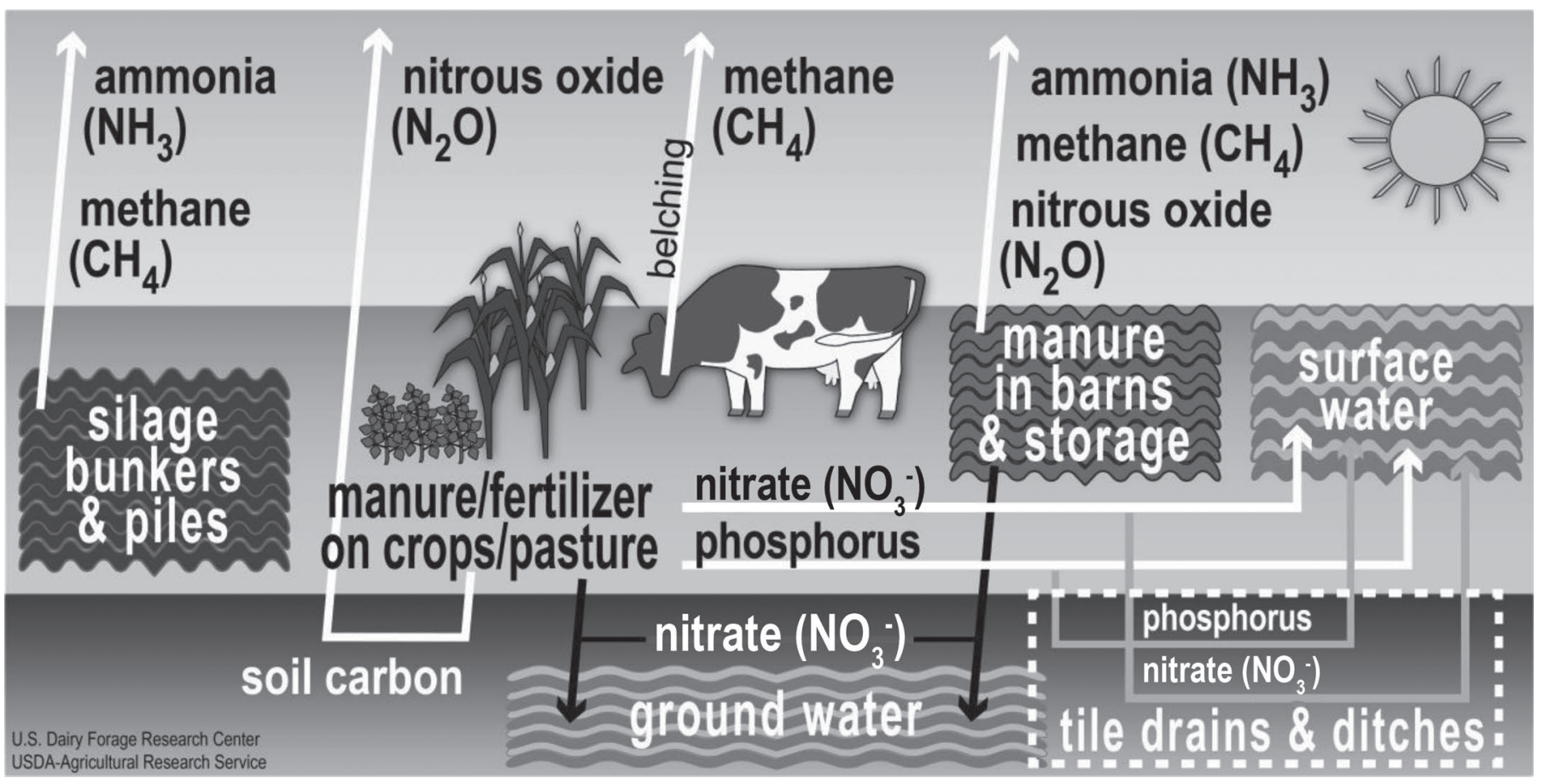

Figure 5. How N, P, and C enter the atmosphere, surface water, and ground water (adapted with permission from US Dairy Forage Research Center, USDA-ARS, Madison, WI). 
ment on local, regional, and global scales (Galloway et al., 2008; Ribaudo et al., 2011; Sutton et al., 2013). On many farms, excessive CP in dairy diets has led to greater excretion of $\mathrm{N}$ in manure and $\mathrm{N}$ loss (Powell and Rotz, 2015). Typical ranges of $\mathrm{N}$ loss from manure are 30 to $40 \%$ via $\mathrm{NH}_{3}$ volatilization, 10 to $30 \%$ by $\mathrm{NO}_{3}{ }^{-}$ leaching, and 2 to $5 \%$ through denitrification (reviewed by Rotz, 2004). Although denitrification affects only a small percentage of applied manure $\mathrm{N}, \mathrm{N}_{2} \mathrm{O}$ contributes to global climate change and ozone depletion, and $\mathrm{N}_{2} \mathrm{O}$ emission rises rapidly as applied $\mathrm{N}$ rates exceed crop needs (Shcherbak et al., 2014). Additionally, high concentrations of $\mathrm{NO}_{3}{ }^{-}$in the groundwater used as drinking water present a human health hazard (Brender et al., 2013), impair fish habitat in cold water streams that are fed by groundwater (Brown et al., 2008), and result in hot spots of $\mathrm{N}_{2} \mathrm{O}$ emissions where groundwater emerges as surface water (Turner et al., 2015).

It is clear that many producers have difficulties managing nutrient loading by manure. For example, more than $70 \%$ of surveyed dairy producers in Minnesota reported applying manure and fertilizer to first-year corn after alfalfa at rates that exceeded nutrient guidelines by up to $300 \mathrm{~kg}$ of N/ha (Yost et al., 2014a). Technical training and perhaps other incentives are needed for dairy farmers to reduce purchased fertilizer input in proportion to the nutrient supplied by manure and by terminated annual and perennial forage stands (Bierman et al., 2012). This is the case whether crop production is an integral part of the dairy farm, or whether they are separate operations that trade feed and manure (Russelle et al., 2007). Substantial environmental advantages will accrue from reintegrating the feed and livestock operations, either on a given operation or among separate, nearby operations. With new tools, manure management may be coordinated, at least at the watershed level, to achieve appropriate loading rates and minimize economic costs and environmental impacts (Sharara et al., 2017).

\section{CLIMATE CHANGE AND WATER AVAILABILITY WILL CHALLENGE FEED PRODUCTION}

Increased surface temperature will raise crop and forage evapotranspiration rates, which, combined with lower rainfall projected for much of the United States, is expected to have profound effects on forage and crop yield and quality. For example, plants with the C3 photosynthetic pathway, such as cool season pasture grasses, small grains, and soybeans, exhibit enhanced $\mathrm{DM}$ accumulation as atmospheric $\mathrm{CO}_{2}$ concentration increases (Tubiello et al., 2007), but there is little effect on C4 plants, such as corn (Wheeler and Reynolds,
2013). At elevated $\mathrm{CO}_{2}$ concentrations, C3 plants also exhibit improved water use efficiency, and therefore reduced sensitivity to lower rainfall (Morgan et al., 2004). However, higher temperatures may accelerate crop maturation, thereby intensifying lignification and reducing forage fiber digestibility and nutritional value (Van Soest, 1994). Higher temperatures also speed the switch to the reproductive phase, reducing the size of the supporting photosynthetic area and pollen viability for grain production (Hatfield et al., 2011).

We may be able to offset these negative consequences of climate change to some degree by improving plant genetics to maintain better nutritive value in the face of moisture and temperature stress. Indeed, recent advances provide some evidence that this avenue should be explored (Bita and Gerats, 2013). Recent research also shows that improving forage fiber digestibility reduced enteric $\mathrm{CH}_{4}$ emissions as well as emissions of $\mathrm{NH}_{3}$ and $\mathrm{N}_{2} \mathrm{O}$ from manure (Hassanat et al., 2017). Additionally, strategic and targeted supplemental irrigation practices that provide optimal, or at least sufficient, soil water at critical plant growth stages could help to offset losses in forage digestibility while preserving water resources (Baker et al., 2012; Hochman et al., 2013).

Potential benefits from a warming climate include longer frost-free periods in northern states and more growing-degree days available for primary or cover crops. But to maintain sustainable grain, forage, and grassland systems in the face of more extreme weather fluctuations, farmers will need to be agile in managing flexible systems and adjusting quickly to environmental fluctuations. Malcolm et al. (2012) projected effects of climate change in 2030 on major crops by region within the United States. Although projected changes in land use were small for the United States as a whole, for some regions, such as the south, larger changes in crop acreage and planting patterns are expected. Hatfield et al. (2017) forecasted substantial yield declines of corn in the Midwest and concluded that more innovation will be required than simply altering agronomic management. Unpredictable and varying weather will make it increasingly difficult to sustain cropping systems with limited diversity (i.e., monocultures or simple 2-phase annual crop rotations). Grasslands may become even more important as a way to diversify farming systems (Sanderson et al., 2009).

Past trends toward larger dairy production units and high stocking rates may be challenged in the future by predicted changes in temperature and precipitation, especially in the southern High Plains and western United States (Diffenbaugh et al., 2015). In contrast, the predicted warming trend for Great Lakes states and the northeastern United States may provide economic 
and environmental advantages of crop diversification on dairy farms in these regions.

Although regions at high risk for drought are increasing (Cook et al., 2015), a geospatial analysis of water use and water stress showed significant dairy production in the United States does not occur in water-stressed areas, with the exception of some areas in California, Arizona, and New Mexico (Matlock et al., 2013). Agricultural water use and conservation, particularly in 17 western states (Schaible and Aillery, 2012), will be challenged by expanding water demands to support population and economic growth; environmental flows; energysector growth; Native American water-right claims; and supply or demand shifts expected with climate change (Diffenbaugh et al., 2015). Irrigated land area (Arizona, California, Colorado, Nevada, New Mexico, and Utah) is likely to decline, with lower-value, water-intensive field and forage crops experiencing the greatest losses (Cooley et al., 2016); additionally, substantial sections of the midwestern United States will become much drier, particularly during the summer months.

The present challenges facing California (Pollak, 2010; Diffenbaugh et al., 2015; Cooley et al., 2016) provide valuable insight, because intensive dairy production systems already have had to face reduced water availability due to years of low rainfall and insufficient replenishment of aquifers. Efforts to replenish aquifers by focused recharge exist, but some aquifers have physically collapsed after groundwater is removed, reducing or eliminating water-storage capacity (Borchers and Carpenter, 2014).

To avoid unsustainable water use, the dairy industry must focus on development of drought-tolerant crops (Heisey and Day-Rubenstein, 2015); shifting to waterefficient and drought-tolerant crops (Marshall et al., 2015); using soil-management practices that increase water retention, such as conservation tillage, crop residue management, or cover crops (Marshall et al., 2015); and improving temperature and precipitation prediction models that collect and integrate farm-level soil, crop yield, and weather information (Walthall et al., 2012). The point here is that, unless unsustainable water use is avoided, we may permanently lose important resources to support crop production in the future.

We expect that the water requirement per unit of fat, protein, and lactose will need to decline to meet both the physical limits of water supply and societal expectations regarding water use by agriculture. Gaining a better understanding of water use for various crops on a per-hectare basis - and also per unit of digestible energy and protein and their potential to elicit a milk response in the cow-will be critical in allowing the industry to adapt to future environmental and economic forces.

\section{CROP DIVERSIFICATION AND CROP ROTATION ON DAIRY FARMS}

Crops traditionally have been chosen based on prevailing economic incentives to produce more forage and grain from fewer hectares. However, we agree with Robertson et al. (2014), that cropland management that takes into consideration clean water, biodiversity benefits, climate stabilization, and long-term soil fertility must become the norm. Additionally, with urban and suburban populations growing and vastly outnumbering farm and rural residents, social acceptability of specific farming practices that affect water use, biodiversity, and the long-term fertility of soils will undoubtedly play a greater role in future policies and regulations (Davis et al., 2012).

In the short term, practices such as cover cropping or intercropping may help achieve some ecosystem services, such as reduction of soil $\mathrm{NO}_{3}{ }^{-}$loss, increased $\mathrm{C}$ sequestration, and increased soil N. For example, in a no-till silage corn system with dairy manure, inclusion of cover or companion crops helped offset the detrimental effects of biomass removal by improving several chemical, physical, and microbial soil properties and overall soil quality (Jokela et al., 2009). Growing corn in a living mulch of kura clover or inter-seeded with red clover, followed by a year of clover forage production, reduced topsoil $\mathrm{NO}_{3}{ }^{-}$concentrations in spring and fall, probably limiting $\mathrm{NO}_{3}{ }^{-}$losses, and increased harvested protein by 26 to $60 \%$ (Grabber et al., 2014). However, Krueger et al. (2012) observed reduced corn yield due to water limitations when a winter rye double crop harvested for forage in spring was included within a continuous corn silage system that received liquid dairy manure annually. Thus, use of double- or cover-cropping likely will improve environmental and ecosystem outcomes, but may increase profit risk as rainfall becomes more spatially variable in areas such as the Midwest.

\section{Perennial Crops Provide Multiple Benefits}

Compared with annual crops and short-term cover crops, perennial forages provide better protection of the soil surface from water and wind erosion, thereby maintaining or enhancing soil productivity and reducing sedimentation of rivers and lakes (Janzen, 2011; Asbjornsen et al., 2014). Because perennials provide a longer period of ground cover than annual crops, they trap more wind-blown sediment, and can capture more $\mathrm{NH}_{3}$ emitted from farming operations, resulting in improved air quality (Flechard et al., 2015). Perennial forages also generally improve soil OM (Chan et al., 2011) and, in the context of diversified cropping systems, support higher populations and activity of soil microor- 
ganisms than annual crops (King and Hofmokel, 2017). Additional benefits of deeply rooted perennial forages include bringing subsoil nutrients into active nutrient cycles; utilizing subsoil moisture to improve water use efficiency; reducing ground water contamination by $\mathrm{NO}_{3}{ }^{-}$(Stewart et al., 1968; Russelle et al., 2001); and adding organic $\mathrm{C}$ to the subsoil in forms that sequester $\mathrm{CO}_{2}$ (Gentile et al., 2005). New varieties of perennial grasses, such as tall fescue, should further improve environmental benefits, given their greater forage yields and opportunities for better nutritional balance for dairy herds (Brink et al., 2010).

Sustainability of cropping systems is greatly enhanced when perennial legumes are included. Alfalfa and other legumes require no energy-intensive $\mathrm{N}$ fertilizers, provided they are nodulated with effective rhizobia that converts $\mathrm{N}_{2}$ gas from the atmosphere into AA from which the plant constructs proteins (Russelle, 2008). On grain farms in the upper Mississippi River basin, fields were approximately in $\mathrm{N}$ balance when more than onehalf of total $\mathrm{N}$ additions came from legume $\mathrm{N}$ sources or when complex crop rotations included both annual and perennial species (Blesh and Drinkwater, 2013). In contrast, fertilizer-based practices in corn-soybean rotations resulted in average annual surpluses of nearly $35 \mathrm{~kg}$ of $\mathrm{N} /$ ha per year. Even in the absence of feed N being returned to the field as manure, mineralization of soil OM and alfalfa residues can supply all or most of the $\mathrm{N}$ required by the subsequent crop, providing an economic benefit to the farmer and to society as a whole. Even young stands of alfalfa can provide sufficient $\mathrm{N}$ (130 to $200 \mathrm{~kg}$ of $\mathrm{N} / \mathrm{ha}$ ) for 1 or $2 \mathrm{yr}$ of corn production (Lory et al., 1995; Lawrence et al., 2008; Yost et al., 2014b,c); this $\mathrm{N}$ credit also represents a significant energy and GHG savings compared with fertilizer manufacture and use.

Grazed pasture represents 1 to $2 \%$ of the DMI of the national dairy herd (based on analysis by Thoma et al., 2013b). A recent USDA (2016) report categorizes 6.7\% of operations as grazing herds. In these reports, grazing operations are defined as those operations where most of the forage consumed is harvested by cows during the growing season. In addition, the USDA (2016) report showed decreases for the number of cows milked in both grazing $(-28 \%)$ and combination $(-7 \%)$ operations between 2014 and the previous 5 yr.

Much of the land used for grazing ruminant livestock does not possess the potential to support intensive grain or fodder crop production for human or animal consumption. Regional constraints to grazing systems also exist. In northern regions, pasture availability varies widely during the season and is limited by the length of the growing season, whereas summer dormancy limits grazing in southern regions. Reduced productivity exhibited by grazing systems also increases both the number of cows and land base required to produce a set amount of milk (Capper et al., 2008). Although profitable (Hanson et al., 1998; Tozer et al., 2003, 2004), socially desirable (Chapinal et al., 2010), and beneficial from the point of view of reduced GHG emissions (Guyader et al., 2016), we predict that pasture-based systems will remain a niche system in the United States or an enhancement to confinement operations, but not a nation-wide solution to sustainability.

\section{Crop Composition Affects Manure Characteristics}

Not only can improved crop selection and rotation reduce environmental degradation, but appropriate changes in the dairy cow diet alters manure composition. The type of forage consumed by dairy cows affects the chemistry of manure, including concentrations of $\mathrm{N}$ in urine and feces, concentrations of fiber fractions in feces, and the relative partitioning of $\mathrm{N}$ into fecal fiber fractions (Sørensen et al., 2003; Powell et al., 2006; Powell et al., 2009). Carbon and N mineralization in soils is affected by concentrations of NDF in feces, amounts of $\mathrm{N}$ in $\mathrm{NDF}$ and $\mathrm{ADF}$, and relative amounts of $\mathrm{N}$ in NDF and ADF excreted in feces (Somda et al., 1995).

Changes in manure composition can alter $\mathrm{N}$ cycling. Manure from cows fed a greater proportion of corn silage than alfalfa silage reduced the concentration of plant-available inorganic $\mathrm{N}$ in soil compared with manure from rations that contained lower proportions of corn silage (Powell et al., 2006). Subsequent whole-farm $\mathrm{N}$ use efficiency may decrease and $\mathrm{N}$ loss increase as corn silage replaces alfalfa in dairy cropping systems. Although lower $\mathrm{N}$ availability from manure derived from corn silage could be overcome with additional fertilizer N (Powell et al., 2016), this strategy may lead to increases in $\mathrm{NO}_{3}{ }^{-}$and $\mathrm{N}_{2} \mathrm{O}$ loss from soils (Randall, 2006).

As dairy producers seek to provide precisely formulated and economical rations to their dairy cows, it is important to balance long- and short-term economic, environmental, and social goals. In particular, the balance between alfalfa and corn in the cropping system on dairy farms is needed to not only optimize milk production (Brito and Broderick, 2003), but also to enhance nutrient cycling, build soil $\mathrm{C}$, and recycle $\mathrm{N}$ and $\mathrm{P}$ to enhance sustainability. This approach, although sustainable, will be more difficult to implement, given the existing trend toward specialization in crop production, but may be supported by policies that encourage more diverse crop rotations.

Cropping strategies that are well managed will trap soil $\mathrm{NO}_{3}{ }^{-}$and also increase soil OM. As awareness of 
water quality issues escalates, we anticipate increased use of perennial-annual crop rotations as well as doubleand triple-cropping (e.g., incorporating crops such as ryegrass and triticale). We foresee dairy farms continuing to maximize the use of their land base to optimize the metabolizable nutrients needed by their cattle from within their cropping system. A continuing challenge will be to provide farmers with tools and the associated knowledge to develop sustainable land use, cropping, and manuring plans, together with ration formulations that provide a consistent and adequate supply of nutrients and minimize manure nutrient excretions and $\mathrm{CH}_{4}$ emissions.

\section{FORAGES AND GRAINS OF THE FUTURE}

Selection criteria for forage crop improvement will need to expand beyond the current focus on dairy cattle productivity to encompass environmental impacts of growing, harvesting, and storing forages, as well as forage effects on manure chemistry and subsequent effects on soil nutrient cycles and the environment.

\section{Advances in Technology to Improve Forage Crops}

The most important nutritional criteria for improving the feeding value of forages are increased fiber digestibility, CP, and NSC (Brummer et al., 2009). The main digestibility impediment for dicotyledonous plants is highly lignified secondary cell walls, which become less digestible with advancing maturity (Jung et al., 2012). Crops for which the negative effects of lignification have been reduced will be a critical dietary forage component fed to highly productive dairy cows in the future.

Brown midrib mutants of corn silage and warm season annual grasses (sorghum and pearl millet) generally have improved cell wall digestibility and support greater solids-corrected milk production (Cherney et al., 1991; Oba and Allen, 1999; Oliver et al., 2004) due to reduced lignin concentration and alteration in the ratio of syringyl to guaiacyl lignin subunits. Similarly, the seedling ferulate ester corn mutant contains less lignin-arabinoxylan crosslinking by ferulate ethers, and consequently has greater cell wall digestibility at silagestage maturity than near-isogenic wild-type corn (Jung and Phillips, 2010) and supports greater DMI and milk production when fed to dairy cows (Jung et al., 2011).

Notwithstanding these examples, traditional plant breeding has actually resulted in minimal reductions in cell wall lignification and improvements in forage digestibility to-date (Jung et al., 2012). However, in an effort to make greater progress, the Consortium for Alfalfa Improvement, a partnership of government, pri- vate nonprofit, and private for-profit entities, has been committed to redesigning alfalfa for dairy cattle by reducing cell-wall lignin content and protein degradation during ruminal fermentation (Bouton, 2007). In 2002, the Consortium for Alfalfa Improvement established the goal of improving utilization of alfalfa by dairy cattle by (1) engineering alfalfa to contain less lignin and (or) altered lignin composition to increase fiber digestion; (2) engineering legumes to produce condensed tannin in leaves; and (3) inserting genes to add polyphenol oxidase (PPO) and o-quinones from red clover into alfalfa (McCaslin et al., 2015). Condensed tannins help protect feed protein both during ensiling and in the rumen, and their benefits and limitations as ruminant livestock feeds have been summarized in several review publications (Waghorn, 2008; Patra and Saxena, 2011). Incorporation of PPO with o-quinones reduces proteolysis in alfalfa forage. Consequently, the expression of PPO with suitable $o$-diphenol substrates is being pursued as a means for improving alfalfa protein utilization by dairy cows (Sullivan and Hatfield, 2006; Sullivan and Zarnowski, 2011). Innovative ration formulation or co-ensiling forage types that have complementary PPO activity and $o$-diphenol content may offer a means to enhance efficiency of protein use by the animal (Marita et al., 2010, 2012).

Development of forages that use water more efficiently or require less water will be critical in the future. Progress on improved drought tolerance of alfalfa has been reported (Lei et al., 2017), but no commercialization has taken place. One transgene event in corn that putatively improves drought tolerance has been approved and commercialized. Drought tolerance traits in both transgenic and standard corn hybrids appear to improve corn yield in stressful environments (Adee et al., 2016). Increasingly, the dairy industry will require improved water use efficiency in commonly fed forage species, such as alfalfa, perennial and annual grass forages, and corn silage.

The extent to which genetically engineered forage crops will play a role in feed production in the long term remains to be seen (Nature, 2017), given the growing concern by some members of the public regarding the use of these technologies in the food supply (Van Eenennaam and Young, 2014). The first genetically engineered feed crops were introduced in 1996 (Van Eenennaam and Young, 2014); their subsequent adoption has been swift. In 2013, genetically engineered varieties were planted on more than $95 \%$ of sugar beet, $93 \%$ of soybean, and $90 \%$ of cotton and corn acres in the United States (Van Eenennaam and Young, 2014). Globally, food-producing animals consume 70 to $90 \%$ of genetically engineered crops. No label is currently required for these crops in the United States, yet many 
states are considering legislation to mandate such labels (CAST, 2014).

Despite societal concerns surrounding use of genetically engineered crops, the CAST (2014) report concluded that (1) no science-based reason exists to single out genetically engineered foods and feeds for mandatory process-based labeling; (2) mandatory labeling based on process abandons the traditional US practice of providing for consumer food preferences through voluntary product differentiation and labeling; (3) market-driven voluntary labeling measures are currently providing consumers with nongenetically engineered choices; and (4) mandatory labeling will increase food costs (CAST, 2014).

\section{Advances in Technology to Improve Grain Crops}

Although our major focus in this article has been on forage crops, if the dairy industry continues to value high levels of milk production, there will be a persistent need to feed starch more efficiently and effectively. This will be achieved with continued research focusing on grain genetics and processing methods that enhance starch digestibility when fed to dairy cattle. Grain particle size, moisture content, and genetics (traits such as vitreousness of the endosperm) all influence starch digestibility (Blasel et al., 2006). The known existence of a relationship between the protein matrix in grain and starch digestibility in the rumen (Larson and Hoffman, 2008) and the dynamic nature of starch digestibility, including the effects of the length of silo storage time, allows for more efficient diets to be formulated that optimize the use of starch from high-moisture grains and silages (Newbold et al., 2006). An excellent review of factors affecting starch digestibility to improve meat and milk production has been published by Giuberti et al. (2013).

Processing methods that improve starch digestibility of cereal grains can be categorized as (1) particle size reduction by rolling or grinding the dried grains or (2) a combination of moisture and heat. Future systems will need to balance the added energy costs associated with grain processing against improved animal performance. Genetic approaches to enhance starch digestibility include selection of corn hybrids that have greater floury (softer) endosperm characteristics (Glenn, 2013). Floury hybrids may have higher ruminal and total-tract starch digestibility than more vitreous hybrids (Ferraretto et al., 2015), although this remains an active topic of research.

Another promising technology involves the recent development of corn varieties that express $\alpha$-amylase directly in the seed endosperm (Urbanchuk and Kowalski, 2009). If proven successful, this novel approach would not only allow dairy producers to more efficiently feed starch, but it would improve ethanol production using existing infrastructure.

Identity preservation of grain from harvest through use (on farm or ethanol plant) represents a possible solution of assuring targeted grain quality, but is a major challenge when trying to introduce or adopt traitspecific grain varieties. The current grain handling and storage infrastructure does not support separating grain sources based on nutritional or other traits. This represents both an opportunity and a challenge for the dairy industry to have access to the desired, and perhaps more expensive, dietary grain traits. Very large dairy farms may be able to contract their grain needs directly with grain producers, but smaller farms will need to rely on an identity preservation and delivery system. This system of delivery also will need to be flexible, given the inherent uncertainties surrounding regional growing conditions that can affect starch content and digestion characteristics.

\section{PERSPECTIVES ON ENSURING SUSTAINABLE CROPPING SYSTEMS}

Burgeoning populations and rising incomes have greatly increased food demand and created vast new opportunities for the US dairy industry. This coincides with heightened concerns of competition between humans and livestock for limited resources, including land to grow food and feed, and overall environmental impacts of animal agriculture including nutrient pollution, GHG emissions, water use, and climate change (Godfrey and Garnett, 2014). Sustainable land use and animal feed and manure management systems are needed to enhance the profitability, resource use efficiency, and environmental outcomes of dairy production.

Increasingly, we must recognize that US agriculture is competing in a market and, thus, is subjected to the myriad forces that affect global economies. Global food security will increasingly become a national priority, and true security must rely on sustainable crop-foragelivestock production systems (Godfrey and Garnett, 2014). We have described 3 main challenges to the sustainability of forage and crop production for dairy, specifically availability of cropland, availability of water, and lack of diversity in crop rotations. Sustainable forage and grain cropping systems for dairy production will need to be more resilient and agile than current management practices, as only then can the industry proactively respond to economic, environmental, social, and regulatory drivers.

Within this context, we proposed the following priority opportunities to enhance the sustainability of cropping systems associated with US dairy farming. Not all 
of these topics have been specifically discussed within this paper, but all will be important to ensure the sustainability of the US dairy industry at mid-century.

- Support multidisciplinary research between animal science and agronomic productivity and ecosystem services to increase cropping system complexity within dairy farm production systems. Inherent physiological and morphological attributes of crops affect feed production and quality, soil nutrient dynamics, water availability, insect pressure, and incidence of weeds and diseases. By rotating different crop types over time (e.g., grasses, legumes, oilseeds, brassicas, and so on) producers can exploit synergistic relationships among crops to reduce input requirements (e.g., following an N-fixing crop with a high N-use crop; Sanderson et al., 2013). Moreover, placement of crops within landscapes that best suits their growth can improve production efficiencies, decrease sediment loss, and support biodiversity conservation. Greater attention to synergistic responses within crop rotations, along with increased awareness of crop-landscape complementarity, will be crucial to optimize multiple ecosystem functions within integrated dairy production systems.

- Develop economic incentives that promote ecosystem services created from integration of perennial legumes and grasses into annual row crop systems. Focus on recycling nutrients and nutrient transformations within soil using dairy manure from cows fed appropriate forage combinations.

- Support development of alfalfa and other forage crops redesigned to increase fiber digestibility and efficiency of protein utilization.

- Increase animal digestion research on cover crops, sorghums, and new crops with greater potential resilience to climate changes within dairy production regions.

- Increase use of perennial grasses and legumes on dairy farms by increasing genetic potential for yield (increasing fiber digestibility), development of novel harvest systems that reduce hindrance from rain damage during harvest, and development of improved grass-legume pasture combinations that maximize seasonal leaf yield with increased fiber digestibility and improved protein utilization.

- Improve productivity of dairy cattle through advances in management, with a specific focus on efficiency of production of milk components (i.e., fat, protein, and lactose), milk quality, and milk flavor and acceptability to consumers.
- Understand citizen expectations about land use for forage production and grazing by agriculture and how this may affect public policies; ideally, focus will be on the development of technologies and management practices that resonate with societal expectations.

In our opinion, development of forage, crop, and grazing land alternatives under regional dairy production systems need to focus on increasing crop and forage yields and enhancing the utilization of the fiber, protein, and starch in dairy cow rations. Crop rotations that support the ecosystem and enhance land utilization will create the economic and environmental resilience needed to achieve the greater crop production necessary to meet the demands for milk production by 2050. Last, we recognize that the social dimension of sustainability for many working within agriculture will be the most challenging and conceptually difficult given that it will require broad stakeholder input, including farmers and the public.

\section{ACKNOWLEDGMENTS}

We thank M. A. G. von Keyserlingk (University of British Columbia) for comments that greatly improved this review and A. D. Wright (Arizona State University), D. Barbano (Cornell University), E. Kebreab (University of California), J. P. Harner (Kansas State University), K. F. Knowlton (Virginia Polytechnic Institute and State University), M. Boggess (USDAARS), M. Stephenson (University of Wisconsin), and R. A. Cady (Elanco) for their contributions through various discussions. We also thank the William $\mathrm{H}$. Miner Agricultural Research Institute (Chazy, NY) and the Innovation Center for US Dairy (Rosemont, IL) for providing the meeting places for face-to-face interaction. Finally, we thank the Cow of the Future project and the Innovation Center for US Dairy for providing partial funding to assist with this review.

\section{REFERENCES}

Adee, E., K. Roozeboom, G. R. Balboa, A. Schlegel, and I. A. Ciampitti. 2016. Drought-tolerant corn hybrids yield more in drought-stressed environments with no penalty in non-stressed environments. Front. Plant Sci. 7:1534. https://doi.org/10.3389/ fpls.2016.01534.

Adom, F., A. Maes, C. Workman, Z. Clayton-Nierderman, G. Thoma, and D. Shonnard. 2012. Regional carbon footprint analysis of dairy feeds for milk production in the USA. Int. J. Life Cycle Assess. 17:520-534.

Asbjornsen, H., V. Hernandez-Santana, M. Liebman, J. Bayala, J. Chen, M. Helmers, C. K. Ong, and L. A. Schulte. 2014. Targeting perennial vegetation in agricultural landscapes for enhancing ecosystem services. Renew. Agric. Food Syst. 29:101-125. 
Baker, J. M., T. J. Griffis, and T. A. Ochsner. 2012. Coupling landscape water storage and supplemental irrigation to increase productivity and improve environmental stewardship in the U.S. Midwest. Water Resour. Res. 48:W05301. https://doi.org/10.1029/ 2011WR011780.

Bierman, P. M., C. J. Rosen, R. T. Venterea, and J. A. Lamb. 2012. Survey of nitrogen fertilizer use on corn in Minn. Agric. Syst. 109:43-52. https://doi.org/10.1016/j.agsy.2012.02.004.

Bita, C. E., and T. Gerats. 2013. Plant tolerance to high temperature in a changing environment: Scientific fundamentals and production of heat stress-tolerant crops. Front. Plant Sci. 4:273. https:// doi.org/10.3389/fpls.2013.00273.

Blasel, H. M., P. C. Hoffman, and R. D. Shaver. 2006. Degree of starch access: An enzymatic method to determine starch degradation potential of corn grain and corn silage. Anim. Feed Sci. Technol. 128:96-107.

Blesh, J., and L. E. Drinkwater. 2013. The impact of nitrogen source and crop rotation on nitrogen mass balances in the Mississippi River Basin. Ecol. Appl. 23:1017-1035.

Blesh, J., and S. A. Wolf. 2014. Transitions to agroecological farming systems in the Mississippi River Basin: Toward an integrated socioecological analysis. Agric. Human Values 31:621-635.

Boogaard, B. K., B. B. Bock, S. J. Oosting, J. S. C. Wiskerke, and A. J. van der Zijpp. 2010. Social acceptance of dairy farming: the ambivalence between the two faces of modernity. J. Agric. Environ. Ethics 24:259-282.

Borchers, J. W., and M. Carpenter. 2014. Land subsidence from groundwater use in California. California Water Foundation. Accessed Feb. 27, 2017. http://www.water.ca.gov/waterplan/ docs/cwpu2013/Final/vol4/groundwater/13Land_Subsidence _Groundwater_Use.pdf.

Bouton, J. 2007. The economic benefits of forage improvement in the United States. Euphytica 154:263-270.

Brender, J. D., P. J. Weyer, P. A. Romitti, B. P. Mohanty, M. U. Shinde, A. M. Vuong, J. R. Sharkey, D. Dwivedi, S. A. Horel, and J. Kantamneni. 2013. Prenatal nitrate intake from drinking water and selected birth defects in offspring of participants in the National Birth Defects Prevention Study. Environ. Health Perspect. 121:1083-1089.

Brink, G. E., M. D. Casler, and N. P. Martin. 2010. Meadow fescue, tall fescue and orchardgrass response to defoliation management. Agron. J. 102:667-674.

Brito, A. F., and G. A. Broderick. 2003. Effects of different dietary ratios of alfalfa and corn silage on milk production and rumen metabolism in lactating dairy cows. J. Dairy Sci. 86(Suppl. 1):62. (Abstr.)

Brown, M. T., K. C. Reiss, M. J. Cohen, J. M. Evans, P. W. Inglett, K. S. Inglett, K. R. Reddy, T. J. Frazer, C. A. Jacoby, E. J. Philips, R. L. Knight, S. K. Notestein, R. G. Hamann, and K. A. McKee. 2008. Summary and synthesis of the available literature on the effects of nutrients on spring organisms and systems. Univ. Florida Water Institute, Gainesville, FL. Accessed Apr. 17, 2017. https:// www.dep.state.fl.us/springs/reports/files/UF_SpringsNutrients Report.pdf.

Brummer, E. C., J. H. Bouton, M. D. Casler, M. H. McCaslin, and B. L. Waldron. 2009. Grasses and legumes: Genetics and plant breeding. Pages 157-172 in Grasslands, Quietness and Strength for a New American Agriculture. W. F. Wedin and S. L. Fales, ed. American Society of Agronomy, Crop Science Society of America, Soil Science Society of America, Madison, WI.

Capper, J. L., R. A. Cady, and D. E. Bauman. 2009. The environmental impact of dairy production: 1944 compared with 2007. J. Anim. Sci. 87:2160-2167.

Capper, J. L., E. Castaneda-Gutierrez, R. A. Cady, and D. E. Bauman. 2008. The environmental impact of recombinant bovine somatotropin (rbST) use in dairy production. Proc. Natl. Acad. Sci. USA 105:9668-9673.

Carter, P. R., and C. C. Sheaffer. 1983. Alfalfa response to soil water deficits. I. Growth, forage quality, yield, water use, and water-use efficiency. Crop Sci. 23:669-675.
Cela, S., Q. M. Ketterings, K. Czymmek, M. Soberon, and C. Rasmussen. 2014. Characterization of nitrogen, phosphorus, and potassium mass balances of dairy farms in New York State. J. Dairy Sci. 97:7614-7632.

Chan, K. Y., M. K. Conyers, G. D. Li, K. R. Helyar, G. Poile, A. Oates, and I. M. Barchia. 2011. Soil carbon dynamics under different cropping and pasture management in temperate Australia: Results of three long-term experiments. Soil Res. 49:320-328.

Chapinal, N., C. Goldhawk, A. M. de Passilé, M. A. G. von Keyserlingk, D. M. Weary, and J. Rushen. 2010. Overnight access to pasture does not reduce milk production or feed intake in dairy cattle. Livest. Sci. 129:104-110.

Cherney, J. H., D. J. R. Cherney, D. E. Akin, and J. D. Axtell. 1991. Potential of brown-midrib, low lignin mutants for improving forage quality. Adv. Agron. 46:157-198.

Cook, B. I., T. R. Ault, and J. E. Smerdon. 2015. Unprecedented 21st century drought risk in the American southwest and central plains. Sci. Adv. 1:e1400082. https://doi.org/10.1126/sciadv.1400082.

Cooley, H., M. Cohen, R. Phurisamban, and G. Gruere. 2016. Water risk hotspots for agriculture: the case of the southwest United States. OECD Food, Agriculture and Fisheries Papers, No. 96, OECD Publishing, Paris. https://doi.org/10.1787/5jlr3bx95v48 -en.

Council for Agricultural Science and Technology (CAST). 2014. The potential impacts of mandatory labeling for genetically engineered food in the United States, Issue Paper 54. CAST, Ames, IA.

Davis, A. S., J. D. Hill, C. A. Chase, A. M. Johanns, and M. Liebmann. 2012. Increasing cropping system diversity balances productivity, profitability and environmental health. PLoS One 7:e47149.

de Klein, C., R. Monaghan, M. Alfaro, C. Gourley, O. Oenema, and M. Powell. 2017. Nitrogen performance indicators for dairy production systems. Soil Res. 55:479-488. https://doi.org/10.1071/ SR16349.

Dietzel, R., M. Liebman, R. Ewing, M. Helmers, R. Horton, M. Jarchow, and S. Archontoulis. 2016. How efficiently do corn- and soybean-based cropping systems use water? A systems modeling analysis. Glob. Chang. Biol. 22:666-681. https://doi.org/10.1111/ gcb.13101.

Diffenbaugh, N. S., D. L. Swain, and D. Touma. 2015. Anthropogenic warming has increased drought risk in California. Proc. Natl. Acad. Sci. USA 112:3931-3936. https://doi.org/10.1073/ pnas. 1422385112 .

Ebeling, A. M., L. G. Bundy, J. M. Powell, and T. W. Andraski. 2002. Dairy diet phosphorus effects on phosphorus losses in runoff from land-applied manure. Soil Sci. Soc. Am. J. 66:284-291.

Fedoroff, N. V. 2015. Food in a future of 10 billion. Agric. Food Sci. 4:11-21.

Ferraretto, L. F., A. C. Fonseca, C. J. Sniffen, A. Formigoni, and R. D. Shaver. 2015. Effect of corn silage hybrids differing in starch and neutral detergent fiber digestibility on lactation performance and total-tract nutrient digestibility by dairy cows. J. Dairy Sci. 98:395-405.

Flechard, C. R., R. S. Massad, B. Loubet, E. Personne, D. Simpson, J. O. Bash, E. J. Cooter, E. Nemitz, and M. A. Sutton. 2015. Advances in understanding, models and parameterizations of biosphere-atmosphere ammonia exchange. Pages 11-84 in Review and Integration of Biosphere-Atmosphere Modelling of Reactive Trace Gases and Volatile Aerosols. R. S. Massad and B. Loubet, ed. Springer, Dordrecht, the Netherlands.

Galloway, J. N., A. R. Townsend, J. W. Erisman, M. Bekunda, Z. Cai, J. F. Freney, L. A. Marteinelli, S. P. Seitzinger, and M. A. Sutton. 2008. Transformations of the nitrogen cycle: Recent trends, questions, and potential solutions. Science 320:889-892.

Gentile, R. M., D. L. Martino, and M. H. Entz. 2005. Influence of perennial forages on subsoil organic carbon in a long-term rotation study in Uruguay. Agric. Ecosyst. Environ. 105:419-423.

Giuberti, G., A. Gallo, F. Masoero, L. F. Ferrareto, P. C. Hoffman, and R. D. Shaver. 2013. Factors affecting starch utilization in large animal food production system: A review. Starch 65:1-19. 
Glenn, F. B. 2013. Introducing leafy floury hybrids for improved silage yield and quality. Pages 1-11 in Proc. Cornell Nutr. Conf. Feed Manufac., East Syracuse, NY. Cornell University, Ithaca, NY.

Godfrey, H. C. J., and T. Garnett. 2014. Food security and sustainable intensification. Phil. Trans. Royal Soc. B 369:20120273. https:// doi.org/10.1098/rstb.2012.0273.

Grabber, J. H., W. E. Jokela, and J. G. Lauer. 2014. Soil nitrogen and forage yields of corn grown with clover or grass companion crops and manure. Agron. J. 106:952-961.

Guyader, J., H. H. Janzen, R. Kroebel, and K. A. Beauchemin. 2016. Forage use to improve environmental sustainability of ruminant production. J. Anim. Sci. 94:3147-3158. https://doi.org/10.2527/ jas.2015-0141.

Hanson, G. D., L. C. Cunningham, M. J. Morehart, and R. L. Parsons. 1998. Profitability of moderate intensive grazing of dairy cows in the northeast. J. Dairy Sci. 81:821-829.

Harter, T., J. H. Viers, D. Liptzin, T. S. Rosenstock, V. B. Jensen, A. D. Hollander, A. McNally, A. M. King, G. Kourakos, E. M. Lopez, N. DeLaMora, A. Fryjoff, K. N. Hung, H. Dzurella, S. Canada, C. Laybourne, J. McKenney, J. Darby, and J. F. Quinn. 2013. Dairies and other sources of nitrate loading to groundwater. Task Report 6. SWRCB Agreement Number 04-184-555. Department of Land, Air, and Water Resources. University of California, Davis. http:// groundwater.ucdavis.edu/files/202724.pdf

Hassanat, F., R. Gervais, and C. Benchaar. 2017. Methane production, ruminal fermentation characteristics, nutrient digestibility, nitrogen excretion, and milk production of dairy cows fed conventional or brown midrib corn silage. J. Dairy Sci. 100:2625-2636.

Hatfield, J. L., K. J. Boote, B. A. Kimball, L. H. Ziska, R. C. Izaurralde, D. Ort, A. M. Thomson, and D. W. Wolfe. 2011. Climate impacts on agriculture: Implications for crop production. Agron. J. 103:351-370.

Hatfield, J. L., L. Wright-Morton, and M. B. Hall. 2017. Vulnerability of grain crops and croplands in the Midwest to climatic variability and adaptation strategies. Clim. Change. https://doi.org/10.1007/ s10584-017-1997-x.

Heisey, P., and K. Day-Rubenstein. 2015. Using Crop Genetic Resources to Help Agriculture Adapt to Climate Change: Economics and Policy. USDA, Economic Research Service, EIB-139. Washington, DC.

Higginbotham, G., and J. Karlin. 2008. The changing nature of dairy rations and how it affects forage demand. 38th California Alfalfa \& Forage Symposium and Western Alfalfa Seed Conf., San Diego, CA. Accessed Feb. 27, 2017. https://urldefense .proofpoint.com/v2/url?u=http-3A__alfalfa.ucdavis.edu -2Bsymposium_proceedings_2008_08-2D15.pdf\&d=DwICAg $\& c=$ euGZstcaTDllvimEN8b7jXrwqOf-v5A_CdpgnVfiiMM\&r= FAWUuTzGzgpMqArTibr-qU5Q9RR-zfu7Xpo7PP3AWWA\&m $=$ Yw5wJXgcwTqRatpJS4m4PpqtaH_fFe5VF_zN5qTeMDU\&s= OX9Q4pzar5rBQRIq9cOOAkf7ONfBkkcpwTzWRsgTKKw\&e=.

Hochman, Z., P. S. Carberry, M. J. Robertson, D. S. Gaydon, L. W Bell, and P. C. McIntosh. 2013. Prospects for ecological intensification of Australian agriculture. Eur. J. Agron. 44:109-123.

Hoekstra, A. Y. 2012. The hidden water resource use behind meat and dairy. Anim. Front. 2:3-8.

Isik, M. 2004. Environmental regulation and the spatial structure of the U.S. dairy sector. Am. J. Agric. Econ. 86:949-962.

Janzen, H. H. 2011. What place for livestock on a re-greening earth? Anim. Feed Sci. Technol. 167:783-796.

Jokela, W. E., J. H. Grabber, D. L. Karlen, T. C. Balser, and D. E. Palmquist. 2009. Cover crop and liquid manure effects on soil quality indicators in a corn silage system. Agron. J. 101:727-737.

Jung, H. G., D. R. Mertens, and R. L. Phillips. 2011. Impact of reduced ferulate-mediated lignin/arabinoxylan cross linking in corn silage on feed intake, digestibility, and milk production. J. Dairy Sci. 94:5124-5137.

Jung, H. J. G., and R. L. Phillips. 2010. Putative seedling ferulate ester (sfe) maize mutant: morphology, biomass yield, and stover cell wall composition and rumen degradability. Crop Sci. 50:403-418.

Jung, H. J. G., D. A. Samac, and G. Sarath. 2012. Modifying crops to increase cell wall digestibility. Plant Sci. 185-186:65-77.
King, A. E., and K. S. Hofmokel. 2017. Diversified cropping systems support greater microbial cycling and retention of carbon and nitrogen. Agric. Ecosyst. Environ. 240:66-76.

Klemme, R. M. 1998. The economics of forage production in a rapidly changing dairy sector. Pages 58-65 in Midwest Dairy Management Conf. Proc., Kansas City, MO. Midwest Dairy Association, St. Paul, MN.

Krueger, E. S., T. E. Ochsner, J. M. Baker, P. M. Porter, and D. C. Reicosky. 2012. Rye-corn silage double-cropping reduces corn yield but improves environmental impacts. Agron. J. 104:888-896.

Lanyon, L. E. 1992. Implications of dairy herd size for farm material transport, plant nutrient management, and water quality. J. Dairy Sci. 75:334-344.

Lanyon, L. E. 2005. Phosphorus, animal nutrition and feeding: overview. Pages 561-586 in Phosphorus: Agriculture and the Environment. J. T. Sims and A. N. Sharpley, ed. Amer. Soc. Agron. Monograph Am. Soc. Agron., Madison, WI.

Larson, J., and P. C. Hoffman. 2008. Technical note: A method to quantify prolamin proteins in corn that are negatively related to starch digestibility in ruminants. J. Dairy Sci. 91:4834-4839.

Lawrence, J. R., Q. M. Ketterings, and J. H. Cherney. 2008. Effect of nitrogen application on yield and quality of silage corn after forage legume-grass. Agron. J. 100:73-79.

Lei, Y., A. Hannoufa, and P. Yu. 2017. The use and gene modification and advanced molecular structure analyses towards improving alfalfa forage. Int. J. Mol. Sci. 18:298-304. https://doi.org/10.3390/ ijms18020298.

Lory, J. A., G. W. Randall, and M. P. Russelle. 1995. Crop sequence effects on response of corn and soil inorganic nitrogen to fertilizer and manure nitrogen. Agron. J. 87:876-883.

MacDonald, J., and D. Newton. 2014. Milk Production Continues Shifting to Large-Scale Farms. Amber Waves. December, 2014. USDA-ERS, Washington, DC.

MacDonald, J. M., J. Cessna, and R. Mosheim. 2016. Changing Structure, Financial Risks, and Government Policy for the U. S. Dairy Industry. ERR-205. USDA-ERS, Washington, DC.

MacDonald, J. M., E. J. O'Donoghue, W. D. McBride, R. F. Nehring, C. L. Sandretto, and R. Mosheim. 2007. Profits, Costs, and the Changing Structure of Dairy Farming. ERR-47. USDA-ERS, Washington, DC.

Malcolm, S., E. Marshall, M. Aillery, P. Heisey, M. Livingston, and K. Day-Rubenstein. 2012. Agricultural Adaptation to a Changing Climate: Economic and Environmental Implications vary by U.S. Region. ERR-136. USDA-ERS, Washington, DC.

Marita, J. M., R. D. Hatfield, and G. Brink. 2010. In vitro proteolytic inhibition, polyphenol oxidase activity, and soluble o-diphenols in grasses and cereals. J. Agric. Food Chem. 58:959-966.

Marita, J. M., R. D. Hatfield, G. E. Brink, and D. R. Mertens. 2012. Co-ensiling temperate grasses to improve protein use efficiency in ruminants. Pages 132-133 in Proc. XVI Intern. Silage Conf., July 2-4, 2012. Hameenlina, Finland. MTT Agrifood Research Finland, University of Helsinki, Finland.

Marshall, E., M. Aillery, S. Malcolm, and R. Williams. 2015. Climate Change, Water Scarcity, and Adaption in the U.S. Field Crop Sector. ERR-201. USDA-ERS, Washington DC.

Matlock, M., G. Thoma, E. Cummings, J. Cothren, M. Leh, and J. Wilson. 2013. Geospatial analysis of potential water use, water stress, and eutrophication impacts from dairy production. Int. Dairy J. 31(Suppl.1):S78-S90.

McCaslin, M., D. Weakley, S. Temple, and P. Reisen. 2015. New technologies in alfalfa. WCDS Adv. Dairy Technol. 27:215-222.

Morgan, J. A., D. E. Pataki, C. Körner, H. Clark, S. J. Del Grosso, J. M. Grünzweig, A. K. Knapp, A. R. Mosier, P. C. D. Newton, P. A. Niklaus, J. B. Nippert, R. S. Nowak, W. J. Parton, H. W. Polley, and M. R. Shaw. 2004. Water relations in grassland and desert ecosystems exposed to elevated atmospheric $\mathrm{CO}_{2}$. Oecologia 140:11-25.

Nature. 2017. Harmonize conflicting regulations for genetically engineered plants and animals (editorial). Nature 546:327-328. https://doi.org/10.1038/546327b. 
Newbold, J. R., E. A. Lewis, L. Lavrijssen, H. J. Brand, H. Vedder, and J. Bakker. 2006. Effect of storage time on ruminal starch degradability in corn silage. J. Dairy Sci. 89(Suppl. 1):94. (Abstr.)

Nickerson, C., R. Ebel, A. Borchers, and F. Carriazo. 2011. Major Uses of Land in the United States, 2007. EIB-89, USDA-ERS, Washington, DC.

Oba, M., and M. S. Allen. 1999. Effects of brown midrib 3 mutation in corn silage on dry matter intake and productivity of high yielding dairy cows. J. Dairy Sci. 82:135-142.

Oliver, A. L., R. J. Grant, and J. F. Pedersen. 2004. Comparison of brown midrib-6 and -18 forage sorghum with conventional sorghum and corn silage in diets of lactating dairy cows. J. Dairy Sci. 87:637-644.

Patra, A. K., and J. Saxena. 2011. Exploitation of dietary tannins to improve rumen metabolism and ruminant nutrition. J. Sci. Food Agric. 91:24-37.

Pollak, J. 2010. California water and the rhetoric of crisis. Berkeley Planning J. 23(1):8. http://escholarship.org/uc/item/6gg4203t

Powell, J. M., T. Barros, M. Danes, M. Aguerre, M. Wattiaux, and K. Reed. 2017. Nitrogen use efficiencies to grow, feed, and recycle manure from the major diet components fed to dairy cows in the USA. Agric. Ecosyst. Environ. 239:271-282.

Powell, J. M., G. A. Broderick, J. H. Grabber, and U. C. Hymes-Fecht. 2009. Effects of forage protein-binding polyphenols on chemistry of dairy excreta. J. Dairy Sci. 92:1765-1769.

Powell, J. M., C. J. P. Gourley, C. A. Rotz, and D. M. Weaver. 2010b. Nitrogen use efficiency: A potential performance indicator and policy tool for dairy farms. Environ. Sci. Policy 13:217-228.

Powell, J. M., D. B. Jackson-Smith, and L. D. Satter. 2002. Phosphorus feeding and manure nutrient recycling on Wisconsin dairy farms. Nutr. Cycl. Agroecosyst. 62:277-286.

Powell, J. M., and C. A. Rotz. 2015. Measures of nitrogen use efficiency in dairy production systems. J. Environ. Qual. 44:336-344.

Powell, J. M., C. A. Rotz, P. A. Vadas, and K. F. Reed. 2016. Substitutions of corn silage, alfalfa silage and corn grain in cow rations impact N use and N loss from dairy farms. Proc. 2016 Internatl. Nitrogen Initiative Conf. Solutions to Improve Nitrogen Use Efficiency for the World, Melbourne, Australia. Accessed Feb. 23, 2017. http://www.ini2016.com/1662/.

Powell, J. M., M. P. Russelle, and N. P. Martin. 2010a. The United States: Trends in the dairy industry and their implications for producers and the environment. Pages 115-139 in Livestock in a Changing Landscape: Regional Insights. P. Gerber, C. de Haan, J. Dijkman, H. A. Mooney, and S. Tarawali, ed. United Nations Food and Agricultural Organization, Island Press, Washington, DC.

Powell, J. M., M. A. Wattiaux, G. A. Broderick, V. R. Moreira, and M. D. Casler. 2006. Dairy diet impacts on fecal chemical properties and nitrogen cycling in soils. Soil Sci. Soc. Am. J. 70:786-794.

Randall, G. 2006. Risks associated with nitrogen rate decisions. Pages 13-14 in Concepts and Rationale for Regional Nitrogen Rate Guidelines for Corn. J. Sawyer, E. Nafzinger, G. Randall, L. Bundy, G. Rehm and B. Joern, ed. Iowa State Univ. Extension Serv., Ames.

Randall, G. W., D. R. Huggins, M. P. Russelle, D. J. Fuchs, W. W. Nelson, and J. L. Anderson. 1997. Nitrate losses through subsurface tile drainage in Conservation Reserve Program, alfalfa, and row crop systems. J. Environ. Qual. 26:1240-1247.

Rankin, M. 2014. Choosing between alfalfa and corn silage. University of Wisconsin, Extension. Accessed Feb. 23, 2017. http://fyi.uwex .edu/forage/corn/.

Redfearn, D. D., and T. G. Bidwell. 2007. Stocking rate: The key to successful livestock production. Oklahoma Cooperative Extension Serv. PSS-2871. Oklahoma State Univ., Stillwater.

Ribaudo, M., J. Delgado, L. Hansen, M. Liningston, R. Mosheim, and J. Williamson. 2011. Nitrogen in Agricultural Systems: Implications for Conservation Policy. Econ. Res. Rep. No. (ERR-127). Sept., 2011. Accessed Sep. 18, 2016. https://www.ers.usda.gov/ webdocs/publications/44918/6767_err127.pdf?v $=41056$.

Robbins, J. A., M. A. G. von Keyserlingk, D. Fraser, and D. M. Weary. 2016. Invited review: Farm size and animal welfare. J. Anim. Sci. 94:5439-5455.
Robertson, G. P., K. L. Gross, S. K. Hamilton, D. A. Landis, T. M. Schmidt, S. S. Snapp, and S. M. Swinton. 2014. Farming for ecosystem services: An ecological approach to production agriculture. Bioscience 64:404-415.

Robinson, P. H. 2008. Recent changes in dairy feed formulation strategies: The current and projected California situation. Pages 111123 in Proc 29th Western Nutrition Conference, Edmonton, AB, Canada. Anim. Nutr. Assoc. Canada, Ottawa, ON.

Rotz, C. A. 2004. Management to reduce nitrogen losses in animal production. J. Anim. Sci. 82(Suppl.):E119-E137.

Russelle, M. P. 2008. Biological dinitrogen fixation in agriculture. Pages 281-359 in Nitrogen in Agricultural Systems. J. S. Schepers and W. R. Raun, ed. American Society of Agronomy, Crop Science Society of America, Soil Science Society of America, Madison, WI.

Russelle, M. P. 2013. The alfalfa yield gap: A review of the evidence. Forage and Grazinglands 11:1. https://doi.org/10.1094/FG-2013 -0002-RV.

Russelle, M. P., M. H. Entz, and A. J. Franzluebbers. 2007. Reconsidering integrated crop-livestock systems in North America. Agron. J. 99:325-334.

Russelle, M. P., J. F. S. Lamb, B. R. Montgomery, D. W. Elsenheimer, B. S. Miller, and C. P. Vance. 2001. Alfalfa rapidly remediates excess inorganic nitrogen at a fertilizer spill site. J. Environ. Qual. $30: 30-36$.

Russomanno, K. L., M. E. Van Amburgh, and R. J. Higgs. 2012. Utilization of byproducts from human food production as feedstuffs for dairy cattle and relationships to greenhouse gas emissions and environmental efficiency. Pages 130-145 in Proc. Cornell Nutr. Conf Feed Manufac., East Syracuse, NY. Cornell Univ., Ithaca, NY.

Saam, H., J. M. Powell, D. Jackson-Smith, B. Bland, and J. Posner. 2005. Use of animal density to estimate manure nutrient recycling ability of Wisconsin dairy farms. Agric. Syst. 84:343-357.

Sanderson, M. A., D. Archer, J. Hendrickson, S. Kronberg, M. Liebig, K. Nichols, M. Schmer, D. Tanaka, and J. Aguilar. 2013. Diversification and ecosystem services for conservation agriculture: outcomes from pastures and integrated crop-livestock systems. Renew. Agric. Food Syst. 28:129-144.

Sanderson, M. A., D. Wedin, and B. Tracey. 2009. Grassland: Definition, origins, extent, and future. Pages 57-74 in Grassland, Quietness and Strength for a New American Agriculture. W. F. Wedin and S. L. Fales, ed. American Society of Agronomy, Crop Science Society of America and Soil Science Society of America. Madison, WI.

Schaible, G. D., and M. P. Aillery. 2012. Water Conservation in Irrigated Agriculture: Trends and Challenges in the Face of Emerging Demands. EIB-99, USDA-ERS, Washington, DC.

Schmit, T. M., R. N. Boisvert, D. Enahoro, and L. E. Chase. 2009 Optimal dairy farm adjustments to increased utilization of corn distillers dried grains with solubles. J. Dairy Sci. 92:6105-6115.

Sharara, M., A. Sampat, L. W. Good, A. S. Smith, P. Porter, V. M. Zavala, R. Larson, and T. Runge. 2017. Spatially explicit methodology for coordinated manure management in shared watersheds. J. Environ. Manage. 192:48-56.

Sharpley, A. N., and J. T. Sims. 2005. Phosphorus in agriculture and the environment. Agron. Monograph 46. ASA, CSSA, and SSSA, Madison, WI.

Shcherbak, I., N. Millar, and G. P. Robertson. 2014. Global meta-analysis of the nonlinear response of soil nitrous oxide $\left(\mathrm{N}_{2} \mathrm{O}\right)$ emissions to fertilizer nitrogen. Proc. Natl. Acad. Sci. USA 111:9199-9204.

Sims, J. T., and A. N. Sharpley. 2005. Phosphorus: Agriculture and the Environment. Agron. Monograph 46. ASA, CSSA, and SSSA, Madison, WI. https://doi.org/10.2134/agronmonogr46.

Somda, Z. C., J. M. Powell, S. Fernandez-Rivera, and J. D. Reed. 1995. Feed factors affecting nutrient excretion by ruminants and fate of nutrients when applied to soil. Pages 227-246 in Livestock and Sustainable Nutrient Cycles in Mixed-Farming Systems of Sub-Sahara Africa. Volume II: Technical Papers, Proc. Int. Conf., Addis Ababa, Ethiopia. J. M. Powell, S. Fernández-Rivera, T. O. Williams, and C. Renard, ed. International Livestock Center for Africa (ILCA), Addis Ababa, Ethiopia. 
Sørensen, P., M. R. Weisbjerg, and P. Lund. 2003. Dietary effects on the composition and plant utilization of nitrogen in dairy cattle manure. J. Agric. Sci. 141:79-91.

Stewart, B. A., F. G. Viets, and G. L. Hutchins. 1968. Agricultures effect on nitrate pollution of groundwater. J. Soil Water Conserv. $23: 13-20$

Sullivan, M. L., and R. D. Hatfield. 2006. Polyphenol oxidase and odiphenols inhibit postharvest proteolysis in red clover and alfalfa. Crop Sci. 46:662-670.

Sullivan, M. L., and R. Zarnowski. 2011. Red clover HCT2, a hydroxycinnamoyl-coenzyme A:malate hydroxycinnamoyl transferase, plays a crucial role in biosynthesis of phaselic acid and other hydroxycinnamoyl-malate esters in vivo. Plant Physiol. 155:10601067.

Sutton, M. A., A. Bleeker, C. M. Howard, M. Bekunda, B. Grizzetti, W. de Vries, H. J. M. van Grinsven, Y. P. Abrol, T. K. Adhya, G. Billen, E. A. Davidson, A. Datta, R. Diaz, J. W. Erisman, X. J. Liu, O. Oenema, C. Palm, N. Raghuram, S. Reis, R. W. Scholz, T. Sims, H. Westhoek, and F. S. Zhang. 2013. Our nutrient world: The challenge to produce more food and energy with less pollution. Global Overview of Nutrient Management. Centre for Ecology and Hydrology, Edinburgh, on behalf of the Global Partnership on Nutrient Management and the International Nitrogen Initiative. Accessed Jul. 11, 2014. http://nora.nerc.ac.uk/500700/ 1/N500700BK.pdf.

Thoma, G., J. Popp, D. Nutter, D. Shonnard, R. Ulrich, M. Matlock, D. Soo Kim, Z. Neiderman, N. Kemper, C. East, and F. Adom. 2013a. Greenhouse gas emissions from milk production in the United States: A cradle-to-grave live cycle analysis circa 2008. Int. Dairy J. 31:S3-S14.

Thoma, G., J. Popp, D. Shonnard, D. Nutter, M. Matlock, R. Ulrich, W. Kellogg, D. Soo Kim, Z. Heiderman, N. Kemper, F. Adom, and C. East. 2013b. Regional analysis of greenhouse gas emissions from USA dairy farms: A cradle to farm-gate assessment of the American dairy industry circa 2008. Int. Dairy J. 21:S29-S40.

Tozer, P. R., F. Bargo, and L. D. Muller. 2003. Economic analysis of feeding systems combining pasture and total mixed ration. J. Dairy Sci. 86:808-818.

Tozer, P. R., F. Bargo, and L. D. Muller. 2004. The effect of pasture allowance and supplementation on feed efficiency and profitability. J. Dairy Sci. 87:2902-2911.

Tricarico, J. M. 2016. Role of dairy cattle in converting feed to food. Pages 49-57 in Proc. 2016 Tri-State Dairy Nutr. Conf., Fort Wayne, IN. Accessed Sep. 15, 2016. http://tristatedairy.org/ Proceedings\%202016/Juan\%20Tricarico.pdf.

Tubiello, F. N., J. F. Soussana, and S. M. Howden. 2007. Crop and pasture response to climate change. Proc. Natl. Acad. Sci. USA 104:19686-19690.

Turner, P. A., T. J. Griffis, X. Lee, J. M. Baker, R. T. Venterea, and J. D. Wood. 2015. Indirect nitrous oxide emissions from streams within the US Corn Belt scale with stream order. Proc. Natl. Acad. Sci. USA 112:9839-9843. https://doi.org/10.1073/pnas .1503598112

Urbanchuk, J. M., and D. J. Kowalski. 2009. Corn amylase: improving the efficiency and environmental footprint of corn to ethanol through plant biotechnology. AgBioForum 12:149-154.

USDA. 2016. Dairy 2014. Dairy Cattle Management Practices in the United States, 2014. USDA-APHIS-VS-CEAH-NAHMS, Fort Collins, CO.

USDA-NASS. 1977. 1974 Census of Agriculture - United States Data. Accessed Jan. 9, 2015. http://usda.mannlib.cornell.edu/usda/ AgCensusImages/1974/01/51/305/Table-32.pdf.

USDA-NASS. 1981. 1978 Census of Agriculture - United States Data. pp. 102-117. Accessed Jan. 9, 2015. http://usda.mannlib.cornell .edu/usda/AgCensusImages/1978/01/51/181/Table-35.pdf.

USDA-NASS. 1984. 1982 Census of Agriculture - United States Data. pp. 116-133. Accessed Jan. 9, 2015. http://usda.mannlib.cornell .edu/usda/AgCensusImages/1982/01/51/121/Table-50.pdf.

USDA-NASS. 1989. 1987 Census of Agriculture-United States Data. pp. 124-143. Accessed Jan. 9, 2015. http://usda.mannlib.cornell .edu/usda/AgCensusImages/1987/01/51/28/Table-53.pdf.
USDA-NASS. 1994. 1992 Census of Agriculture - United States Data. pp. 129-148. Accessed Jan. 9, 2015. http://usda.mannlib.cornell .edu/usda/AgCensusImages/1992/01/51/1574/Table-51.pdf.

USDA-NASS. 1999. 1997 Census of Agriculture - United States Data. pp. 140-161. Accessed Jan. 9, 2015. http://usda.mannlib.cornell .edu/usda/AgCensusImages/1997/01/51/1604/Table-51.pdf.

USDA-NASS. 2004. 2002 Census of Agriculture-United States Data pp. 162-187. Accessed Jan. 9, 2015. http://usda.mannlib.cornell .edu/usda/AgCensusImages/2002/01/51/1708/Table-59.pdf.

USDA-NASS. 2009. 2007 Census of Agriculture - United States Data. pp. 178-205. Accessed Jan. 9, 2015. https://www.agcensus.usda .gov/Publications/2007/Full_Report/Volume_1,_Chapter_1_US/ st99_1_062_062.pdf.

USDA-NASS. 2014. 2012 Census of Agriculture - United States Data. pp. 174-203. Accessed Jan. 9, 2015. https://www.agcensus.usda .gov/Publications/2012/Full_Report/Volume_1,_Chapter_1_US/ st99_1_068_068.pdf

Vadas, P. A., L. W. Good, J. C. Panuska, D. L. Busch, and R. A. Larson. 2015. A new model of phosphorus loss in runoff from outdoor cattle lots. Trans. ASAE 58:1035-1045.

Van Amburgh, M. E., E. A. Collao-Saenz, R. J. Higgs, D. A. Ross, E. B. Recktenwald, E. Raffrenato, L. E. Chase, T. R. Overton, J. K. Mills, and A. Foskolos. 2015. The Cornell Net Carbohydrate and Protein System: Updates to the model and evaluation of version 6.5. J. Dairy Sci. 98:6361-6380.

Van Eenennaam, A. L., and A. E. Young. 2014. Prevalence and impacts of genetically engineered feedstuffs on livestock populations. J. Anim. Sci. 92:4255-4278.

Van Middelaar, C. E., J. Dijkstra, P. B. Berentsen, and J. De Boer. 2014. Cost-effectiveness of feeding strategies to reduce greenhouse gas emissions from dairy farming. J. Dairy Sci. 97:2427-2439.

Van Soest, P. J. 1994. Nutritional Ecology of the Ruminant. Comstock University Press, Cornell University, Ithaca, NY

Veltman, K., C. D. Jones, R. Gaillard, S. Cela, L. Chase, B. D. Duval, R. C. Izaurralde, Q. M. Ketterings, C. Li, M. Matlock, A. Reddy, A. Rotz, W. Salas, P. Vadas, and O. Jolliet. 2017. Comparison of process-based models to quantify nutrient flows and greenhouse gas emissions associated with milk production. Agric. Ecosyst. Environ. 237:31-44

Waghorn, G. C. 2008. Beneficial and detrimental effects of dietary condensed tannins for sustainable sheep and goat production-progress and challenges. Anim. Feed Sci. Technol. 147:116-139.

Walthall, C. L., J. Hatfield, P. Backlund, L. Lengnick, E. Marshall, M. Walsh, S. Adkins, M. Aillery, E. A. Ainsworth, C. Ammann, C. J. Anderson, I. Bartomeus, L. H. Baumgard, F. Booker, B. Bradley, D. M. Blumenthal, J. Bunce, K. Burkey, S. M. Dabney, J. A. Delgado, J. Dukes, A. Funk, K. Garrett, M. Glenn, D. A. Grantz, D. Goodrich, S. Hu, R. C. Izaurralde, R. A. C. Jones, S.-H. Kim, A. D. B. Leaky, K. Lewers, T. L. Mader, A. McClung, J. Morgan, D. J. Muth, M. Nearing, D. M. Oosterhuis, D. Ort, C. Parmesan, W. T. Pettigrew, W. Polley, R. Rader, C. Rice, M. Rivington, E. Rosskopf, W. A. Salas, L. E. Sollenberger, R. Srygley, C. Stöckle, E. S. Takle, D. Timlin, J. W. White, R. Winfree, L. Wright-Morton, and L. H. Ziska. 2012. Climate Change and Agriculture in the United States: Effects and Adaptation. USDA Technical Bull. 1935, Washington, DC.

Wheeler, T. R., and C. K. Reynolds. 2013. Predicting the risks from climate change to forage and crop production for animal feed Anim. Front. 3:36-41.

Yost, M. A., J. A. Coulter, M. P. Russelle, and M. A. Davenport. 2014a. Opportunities exist to improve alfalfa and manure nitrogen crediting in corn following alfalfa. Agron. J. 106:2098-2106.

Yost, M. A., T. F. Morris, M. P. Russelle, and J. A. Coulter. 2014b. Second-year corn after alfalfa often requires no fertilizer nitrogen. Agron. J. 106:659-669.

Yost, M. A., M. P. Russelle, and J. A. Coulter. 2014c. Field-specific fertilizer nitrogen requirements for first-year corn following alfalfa. Agron. J. 106:645-658. 